\title{
Regional variation in adipose tissue insulin action and GLUT4 glucose transporter expression in severely obese premenopausal women
}

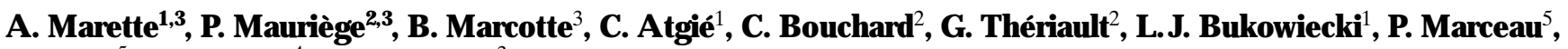 \\ S. Biron ${ }^{5}$, A . N adeau ${ }^{4}$, J.-P. D esprés ${ }^{3}$
}

${ }^{1}$ Department of Physiology, Faculty of Medicine, Laval University, Quebec, Canada

${ }^{2}$ Physical Activity Sciences Laboratory, Laval University, Quebec, Canada

${ }^{3}$ Lipid Research Center, CHUL Medical Research Center, Quebec, Canada

${ }^{4}$ Diabetes Research Unit, CHUL Medical Research Center, Quebec, Canada

${ }^{5}$ Department of Surgery, Laval Hospital, Québec, Canada

Summary Insulin action and GLUT4 expression were examined in adipose tissue of severely obese premenopausal women undergoing gastrointestinal surgery. Fat samples were taken from three different anatomical regions: the subcutaneous abdominal site, the round ligament (deep abdominal properitoneal fat), and the greater omentum (deep abdominal intraperitoneal fat). The stimulatory effect of insulin on glucose transport and the ability of the hormone to inhibit lipolysis were determined in adipocytes isolated from these three adipose depots. Insulin stimulated glucose transport 2-3 times over basal rates in all adipocytes. However, round ligament adipose cells showed a significantly greater responsiveness to insulin when compared to subcutaneous and omental adipocytes. Round ligament fat cells also displayed the greatest sensitivity and maximal antilipolytic response to insulin. We also investigated whether regional differences in fat cell insulin-stimulated glucose transport were linked to a differential expression of the GLUT4 glucose transporter. GLUT4 protein content in total membranes was 5 and 2.2 times greater in round ligament adipose tissue than in subcutaneous and omental fat depots, respectively. Moreover, GLUT4 mRNA levels were 2.1 and 3 times higher in round ligament than in subcutaneous or omental adipose tissues, respectively. Adipose tissue GLUT4 protein content was strongly and negatively associated $(r=-0.79$ to $-0.89, p<0.01)$ with the waist-to-hip ratio but not with total adiposity. In conclusion, these results demonstrate the existence of site differences in adipose tissue insulin action in morbidly obese women. The greater insulin effect on glucose transport in round ligament adipocytes was associated with a higher expression of GLUT4 when compared to subcutaneous abdominal and omental fat cells. Moreover, despite the regional variation in GLUT4 expression, an increased proportion of abdominal fat was found to be associated with lower levels of GLUT4 in all adipose regions investigated. [Diabetologia (1997) 40: 590-598]

Keywords Adipocyte, fat, glucose transport, lipolysis, adenosine.
Received: 8 October 1996 and in revised form: 28 January 1997

Corresponding author: Dr. A. Marette, Department of Physiology and Lipid Research Unit, Laval University Hospital Research Center, 2705, Laurier Bld, Ste-Foy, (Québec), Canada, G1V 4G2

A bbreviations: BSA, Bovine serum albumin; PCR, polymerase chain reaction; NEFA, non-esterified fatty acids; KRBA, Kreb's-Ringer bicarbonate buffer with $4 \%$ BSA; ADA, adenosine deaminase; PVDF, polyvinylidene difluoride; RT, reverse transcriptase; GAPDH, glyceraldehyde phosphate dehydrogenase; HEPES, 4-(2-hydroxyethyl)-1-piperazineethane sulphonic acid.
It is now well-documented that insulin resistance is closely associated with the accumulation of fat in the intra-abdominal region $[1,2]$. Previous studies have shown that whole-body insulin-mediated glucose disposal (measured by the euglycaemic clamp technique) is strongly and negatively correlated with visceral fat accretion, particularly when abdominal adiposity is directly determined by computed tomography or X-ray absorptiometry in both obese and healthy men [3,4], as well as in normal and overweight women [5]. Intra-abdominal obesity is associated with an increased portal non-esterified fatty acid (NEFA) flux which may lead to a reduced hepatic 
insulin extraction, elevated lipoprotein production, and increased gluconeogenesis [6-8], all hallmarks of insulin resistance. However, the pathophysiological mechanism(s) responsible for increased portal NEFA production in visceral obesity remain to be clarified.

Insulin increases the storage of substrate molecules in adipose cells by modulating two main pathways; it stimulates glucose uptake and lipogenesis, and inhibits lipolysis. Most of the glucose incorporated into adipocytes in the presence of insulin is used for re-esterification of fatty acids [9], but a significant proportion of glucose can also be released as lactate in large adipose cells $[10,11]$. On the other hand, insulin is one of the most potent modulators of lipolysis and its antilipolytic effect is observed at low physiological concentrations (1-1000 pmol/l). Thus, the magnitude of insulin action on both glucose transport and lipolysis is believed to control, to a significant degree, the storage or net release of fatty acids by adipocytes [12]. Other important modulators of fatty acid turnover in adipose cells are catecholamines, through their $\alpha_{2}$-adrenoceptor-mediated inhibitory and their $\beta$-adrenoceptor-mediated stimulatory effects, as well as adenosine, a nucleotide released by fat cells that blunts both basal and stimulated lipolysis [12]. Site differences in the action of catecholamines, insulin, and adenosine on human adipose tissue lipolysis have already been shown in numerous studies [see $(2,7,13)$ for reviews]. However, few studies have looked at possible differences in insulin action on glucose transport. Regional variation in insulin-stimulated glucose uptake has been reported in freshly isolated adipocytes [14] and newly differentiated cultured fat cells [15] obtained from epididymal, retroperitoneal, and dorsal subcutaneous tissues of rats. However, to the best of our knowledge, direct comparisons of insulin action between subcutaneous and intra-abdominal adipose regions have not yet been reported in either rats or humans.

Thus, the principal goal of the present study was to examine whether insulin action on glucose transport and antilipolysis are subjected to regional variations in morbidly obese individuals. Our working hypothesis was that deep abdominal fat cells may be less sensitive to insulin action on glucose transport and antilipolysis than subcutaneous adipocytes, thus contributing to enhance NEFA release in the portal circulation. The stimulatory effect of insulin on glucose transport and the antilipolytic response to the hormone were compared in adipocytes isolated from two intra-abdominal sites [round ligament (or properitoneal) and omental] and from the subcutaneous abdominal region. Furthermore, we have attempted to identify the molecular mechanisms responsible for the putative site differences in the effect of insulin on adipocyte glucose transport by measuring the expression of the insulin-responsive GLUT4 glucose transporter, the main transporter isoform of adipose cells. Our results reveal the presence of regional variation in both insulin action and GLUT4 transporter expression in adipocytes. Surprisingly, however, the most insulin-responsive and GLUT4-enriched fat depot was found to be the round ligament. The physiological implications of these findings are discussed.

\section{Subjects and methods}

Selection of patients. The subjects of the present study were nine massively obese premenopausal women undergoing biliopancreatic diversion at the Laval Hospital of Québec. None of the patients had evidence of chronic disease (diabetes mellitus, cardiomyopathy, or endocrine disorders). Their body weight was stable at the time of the study. No subject had been either on a diet or involved in a slimming programme during the previous 6 months. All the women were non-smokers and moderate alcohol consumers. They signed an informed consent document, and the study was approved by the medical ethics committee. Subjects had fasted overnight before adipose tissue removal. General balanced anaesthesia was induced by a shortacting barbiturate and maintained by fentanyl and a mixture of oxygen and nitrous oxide. The patients did not receive drugs acting on the autonomic nervous system or modifying catecholamine levels. Adipose tissue samples were obtained within less than $30 \mathrm{~min}$ from the following sites. As soon as the abdomen was opened, adipose tissue samples were obtained from three different sites: first, from the subcutaneous abdominal wall, second from the round ligament, and third from the greater omentum. These adipose locations were chosen as representative of three different anatomical regions: 1) the subcutaneous fat which is not in contact with the peritoneum;2) the round ligament fat which is in contact with the peritoneum and is here considered as pro-peritoneal fat; 3 ) the omental (epiploic) fat which is located within the abdominal cavity. The two latter adipose tissues have been classified as intra-abdominal depots because of their anatomic association with the peritoneum and both are drained by the portal vein [16].

Total body fat and regional fat distribution. Body density was determined by the underwater weighing technique [17] and percent body fat was derived from body density [18]. Pulmonary residual volume was measured using the helium dilution method [19]. Fat mass was obtained by multiplying percent body fat by body weight. Fat-free mass was calculated as total body weight minus fat mass. Waist and hip girths were measured following the procedures recommended at the Airlie Conference [20] and the ratio of the waist-to-hip circumferences was calculated.

M etabolic determinations. Blood samples were obtained from an antecubital vein in the morning after a 12 -h fast. Plasma glucose and triglycerides were measured enzymatically, whereas plasma insulin was measured by radioimmunoassay using precipitation with polyethylene glycol, as previously described [21].

A dipocyte isolation. After collection, adipose tissue was quickly transferred to the laboratory, in saline $(0.9 \% \mathrm{NaCl}) 4-(2-$ hydroxyethyl)-1-piperazineethanesulphonic acid (HEPES) $(5 \mathrm{mmol} / \mathrm{l})(\mathrm{pH} 7.4)$ and used within a 15-min period. Adipocytes were isolated according to the method of Rodbell [22] in a Krebs-Ringer bicarbonate buffer ( $\mathrm{pH} 7.4)$ containing $4 \%$ 
bovine serum albumin (KRBA) and $5 \mathrm{mmol} / \mathrm{l}$ glucose, plus $1 \mathrm{mg} / \mathrm{ml}$ collagenase as already described [23, 24]. Digestion took place in a shaking water bath under a gas phase of $95 \%$ $\mathrm{O}_{2}$ and $5 \% \mathrm{CO}_{2}$, for $40 \mathrm{~min}$ at $37^{\circ} \mathrm{C}$. The suspension was then filtered and the cellular filtrate obtained was rinsed 3 times with $5 \mathrm{ml}$ of KRBA. Isolated adipocytes were finally resuspended in KRBA and used for determinations of glucose metabolism and lipolysis, as described in the following sections.

G lucose transport in isolated adipocytes. Glucose transport was determined using $\mathrm{D}-\left[{ }^{14} \mathrm{C}(\mathrm{U})\right]$-glucose as previously described by Kashiwagi et al. [25] with minor modifications [26]. The cell suspension (approximately $2 \times 10^{5}$ cells $/ \mathrm{ml}$ ) was incubated with or without various concentrations of insulin at $37^{\circ} \mathrm{C}$ in $500 \mu \mathrm{l}$ in Krebs-Ringer bicarbonate-HEPES buffer ( $\mathrm{pH} 7.4$ ) containing $4 \%$ fatty acid-free albumin and trace $(400 \mathrm{nmol} / \mathrm{l})$ amounts of [U- $\left.{ }^{14} \mathrm{C}\right]$-D-glucose $(0.1 \mu \mathrm{Ci})$. Cell suspensions were incubated for $60 \mathrm{~min}$ at $37^{\circ} \mathrm{C}$ with continuous shaking at $40 \mathrm{cy}$ cles/min. Transport was terminated by rapid centrifugation (30 s) of $300 \mu \mathrm{l}$ of the cell suspensions in $0.5 \mathrm{ml}$ Eppendorf tubes containing $100 \mu \mathrm{l}$ of dynonyl phthalate. Cell-associated radioactivity as well as that of the medium were measured by scintillation counting using an LKB scintillation counter (1215 Rackbeta) equipped with a quenching correction program. Uptake values were corrected for the amount of $D-\left[{ }^{14} \mathrm{C}(\mathrm{U})\right]$-glucose trapped in the extracellular water space by centrifugation of cell samples just after the addition of the radiolabelled glucose. The glucose transport rate was expressed as the glucose clearance rate in $\left(\mathrm{fL} \cdot \mathrm{s}^{-1} \cdot\right.$ cell $\left.^{-1}\right)$ where clearance $=$ volume in medium $\times(\mathrm{dpm}$ in cells/dpm in medium $)$.

M easurement of adipocyte lipolysis. Extracellular glycerol release was used as the indicator of adipocyte lipolysis and was determined as previously described (21) using a cell concentration of 500-1000 cells/100 $\mu$ l. NADH concentration was measured by bioluminescence with a luciferase solution, using a 1251 LKB Wallac luminometer. Fat cell diameters were determined using a Leitz microscope equipped with a graduated ocular (Rockleigh, N.J., USA). Mean fat cell diameter was assessed from the measurement of at least 500 cells, and the density of triolein (0.915) was used to transform adipose cell volume into fat cell weight [23]. When the antilipolytic effect of insulin was investigated, the incubation buffer was supplemented with $5 \mu \mathrm{g} / \mathrm{ml}$ adenosine deaminase (ADA) to remove adenosine released in the incubation medium by isolated adipocytes. Insulin responsiveness (maximal antilipolytic response) was given as percent inhibition of ADA-stimulated lipolysis [(ADA values minus insulin $(1 \mathrm{nmol} / \mathrm{l})$ values divided by ADA values $) \times 100)$ ] Sensitivity was considered as the drug concentration giving half-maximal antilipolysis $\left(\mathrm{IC}_{50}\right)$ and was evaluated by logarithmic conversion from each dose-response curve.

I solation of adipose tissue membranes. Adipose tissue samples (50-100 mg) were homogenized in 10 volumes of ice-cold HEPES-sucrose buffer (20 mmol/1 HEPES, pH 7.4, $4 \mathrm{mmol} / 1$ EDTA, $250 \mathrm{mmol} / \mathrm{l}$ sucrose), containing a cocktail of freshly added protease inhibitors (200 mmol/l) (PMSF), $1 \mathrm{mmol} / \mathrm{l} \mathrm{leu}-$ peptin, $1 \mathrm{mmol} / 1$ pepstatin A, $10 \mathrm{mmol} / 1 \mathrm{E} 64)$. The homogenates were centrifuged at $2000 \mathrm{~g}$ for $5 \mathrm{~min}$ at $4{ }^{\circ} \mathrm{C}$. The supernatant was carefully removed from both the pellet (cell debris and nuclei) and the fat cake then was centrifuged at $150000 \mathrm{~g}$ for $90 \mathrm{~min}$ at $4^{\circ} \mathrm{C}$. The membrane pellet was re-suspended in $100 \mu \mathrm{l}$ of HEPES-sucrose buffer and protein concentrations were determined by the bicinconinic acid assay (Pierce, Rockford, IL, USA), using bovine serum albumin (BSA) as standard.
Electrophoresis and Western blotting. Membrane proteins (5 $\mu \mathrm{g}$ ) were subjected to sodium dodecyl sulphate polyacrylamide gel electrophoresis (SDS-PAGE) on 7.5 or $10 \%$ polyacrylamide gels as described by Laemmli [27] and electrophoretically transferred to polyvinylidene difluoride (PVDF) filter membranes for $2 \mathrm{~h}$ as previously described [28]. PVDF membranes were incubated for $1 \mathrm{~h}$ at room temperature with buffer I (50 mmol/l Tris- $\mathrm{HCl}, \mathrm{pH} 7.4,150 \mathrm{mmol} / \mathrm{l} \mathrm{NaCl})$ containing $0.04 \%$ Nonidet P-40 and $0.05 \%$ Tween-20 and $3 \%$ BSA, followed by overnight incubation at $4{ }^{\circ} \mathrm{C}$ with the specific antiGLUT4 antibody. The PVDF membranes were then washed for $30 \mathrm{~min}$, followed by a 1-h incubation with anti-rabbit immunoglobulin $\mathrm{G}$ conjugated to horseradish peroxidase in buffer I containing $1 \%$ BSA. The PVDF membranes were washed for $30 \mathrm{~min}$ in buffer I, and the immunoreactive bands detected by the enhanced chemiluminescence method. In preliminary experiments using $10 \%$ polyacrylamide gels, we found that the polyclonal anti-GLUT4 antibody reacted with two bands, probably representing different glycosylated forms of the GLUT4 protein. It is believed that both bands represent GLUT4 for the following reasons: 1) the same two bands were also observed when using the monoclonal anti-GLUT4 antibody 1F8 (East Acres Biologicals, Southbridge, Mass., USA); 2) both bands were protected when the polyclonal antiGLUT4 antibody was pre-adsorbed with a peptide corresponding to the last 20 amino acids of the carboxyl terminus region of GLUT4 (Marette et al., unpublished observation). In following experiments, $7.5 \%$ polyacrylamide gels were used to optimize the resolution of these two bands. Autoradiographs were quantitated by laser scanning densitometry using the "BioImage-Visage 110S" software from Millipore Corporation (Ann Arbor, Mich., USA). A control membrane sample was run on every gel and used for comparing samples from different gels.

RNA extraction and determination of GLUT4 mRNA. GLUT4 mRNA levels were determined using a semi-quantitative polymerase chain reaction (PCR) approach, as previously described [29]. Glyceraldehyde phosphate dehydrogenase (GAPDH) mRNA was also measured and was used as a control for the reverse transcriptase (RT)-PCR assay [30]. In preliminary studies, we have verified that GAPDH mRNA was expressed at similar levels in different human adipose depots as well as in various rat tissues such as the brain, heart, skeletal muscle, and liver (data not shown). Total cellular RNA from $50-100 \mathrm{mg}$ of human adipose tissue was purified using guanidium thiocyanate-phenol-chloroform extraction [31]. cDNA synthesis was performed with 200 units of Moloney murine leukaemia virus reverse transcriptase (Gibco BRL Canadian life tech., Burlington on, Canada) using 200-300 ng of total RNA in $20 \mu \mathrm{l}$ of RT buffer $(50 \mathrm{mmol} / \mathrm{l}$ Tris- $\mathrm{HCl}, \mathrm{pH} 8.3$, $75 \mathrm{mmol} / 1 \mathrm{KCl}, 3 \mathrm{mmol} / \mathrm{l} \mathrm{MgCl}_{2}$ and $10 \mathrm{mmol} / \mathrm{l}$ dithiothreitol (DTT) containing each $1 \mathrm{mmol} / 1 \mathrm{dNTP}$ and 8 pmol GLUT4 antisense primer or GAPDH antisense primer. The reaction was performed at $42^{\circ} \mathrm{C}$ during $1 \mathrm{~h}$ and the enzyme was then denatured at $95^{\circ} \mathrm{C}$ for $10 \mathrm{~min}$. Samples were then supplemented with $3 \mu \mathrm{l}$ of $10 \times$ PCR buffer $(1 \times$ PCR buffer: $33.3 \mathrm{mmol} / 1$ $\mathrm{KCl}$ and $3 \mathrm{mmol} / \mathrm{l} \mathrm{MgCl}_{2}$ ), $8 \mathrm{pmol}$ of GLUT4 sense primer or GAPDH sense primer and water to $30 \mu \mathrm{l}$. In some experiments a trace amount of $\left[\alpha-{ }^{32} \mathrm{P}\right] \mathrm{dCTP}$ was added to the reaction mixture. cDNAs were denatured for $5 \mathrm{~min}$ at $94^{\circ} \mathrm{C}$, cooled to $72^{\circ} \mathrm{C}$ and then 1 unit of Thermophylus aquaticus DNA polymerase (Boehringer, Mannheim, Laval, Qué, Can) was added to each sample. Amplification was performed as follows: $30 \mathrm{cy}-$ cles of temperature $\left(94^{\circ} \mathrm{C}, 1 \mathrm{~min} ; 60^{\circ} \mathrm{C}, 1 \mathrm{~min} ; 72^{\circ} \mathrm{C}, 1 \mathrm{~min}\right.$ with extension of $3 \mathrm{~s}$ each cycle) in a temperature cycler (DNA Thermal Cycler, Perkin-Elmer, Mississauga, ont. Can.). Sequences of the antisense and sense oligonucleotides 
Table 1. Physical and fasting metabolic characteristics of the subjects

\begin{tabular}{lcl}
\hline & Mean \pm SD & Range \\
\hline Age (years) & $37 \pm 6$ & $27-48$ \\
Body weight $(\mathrm{kg})$ & $112 \pm 17$ & $83-140$ \\
Body mass index $\left(\mathrm{kg} / \mathrm{m}^{2}\right)$ & $45 \pm 5$ & $37-51$ \\
Body fat $(\%)$ & $58 \pm 5$ & $50-66$ \\
Fat mass $(\mathrm{kg})$ & $65 \pm 14$ & $41-89$ \\
Waist circumference $(\mathrm{cm})$ & $113 \pm 9$ & $106-132$ \\
Hip circumference $(\mathrm{cm})$ & $136 \pm 14$ & $117-158$ \\
Waist-to-hip ratio & $0.84 \pm 0.06$ & $4.8-7.4$ \\
Glucose $(\mathrm{mmol} / \mathrm{l})$ & $5.5 \pm 0.8$ & $64-285$ \\
Triglycerides $(\mathrm{mmol} / \mathrm{l})$ & $1.61 \pm 0.76$ & $1.11-3.57$ \\
\hline
\end{tabular}

were as follows: 5'-CAAATAGAAGGAAGACGTAG-3' and 5'-CATAGGAGCTGGTGTGGTCA-3' for GLUT-4 and 5'AGATCCACAACGGATACATT-3' and 5'-TCCCTCAAGATTGTCAGCAA-3' for GAPDH. The expected sizes of amplification products were 382 base pairs (bp) for GLUT4 and $331 \mathrm{bp}$ for GAPDH. In preliminary experiments with adipose tissue RNA ranging from $100-1000 \mathrm{ng}$, it was verified that both GLUT4 and GAPDH are amplified linearly using the above PCR conditions. Moreover, the identity of the amplified products was confirmed by the ability of restriction enzymes to yield DNA fragments corresponding to the expected sizes for GLUT4 and GAPDH (data not shown).

Amplification products were run in $12 \%$ acrylamide gels, stained in ethidium bromide and fluorescence associated with DNA bands was measured using a scanner BioImage-Visage $110 \mathrm{~S}$ from Millipore Corporation. In some experiments, [ $\alpha-$ ${ }^{32} \mathrm{P}$ ]dCTP-labelled GLUT4 and GAPDH DNA bands on dried acrylamide gels were exposed to X-ray films for densitometric analysis. Since we found very similar results whether GLUT4/ GAPDH ratios were determined from scanning ethidium bromide or ${ }^{32} \mathrm{P}$-labelled bands, only the former quantification was used in the present study.

D rugs and chemicals. D- $\left[{ }^{14} \mathrm{C}(\mathrm{U})\right]$-glucose (Specific activity: $360 \mathrm{mCi} / \mathrm{mmol}$ ) was purchased from New England Nuclear (Boston, Mass., USA). Collagenase, BSA, ADA, and enzymes for glycerol assays were obtained from Boehringer. Insulin (Iletin II) (500 IU/ml) came from Eli Lilly (Indianapolis, Ind., USA). The polyclonal GLUT4-specific antibody (IRGT) was obtained from East Acres Biologicals. Anti-rabbit immunoglobulin $\mathrm{G}$ conjugated to horseradish peroxidase and reagents for chemiluminescence detection were purchased from Amersham (Oakville, Ontario, Canada). All other chemicals were of the highest purity grade commercially available.

Statistical analysis. The overall regional difference effect was first tested by analysis of variance and multiple comparisons among the three fat depots were handled with the post-hoc Fisher's protected least-squares difference test. Relationships between two variables were evaluated by Pearson's correlation coefficient.

\section{Results}

The subjects' characteristics are summarized in Table 1 . These women were severely obese, as shown by the mean percentage of body fat $(58 \pm 5 \%)$ and body mass index values (reaching $45 \pm 5 \mathrm{~kg} / \mathrm{m}^{2}$ ).
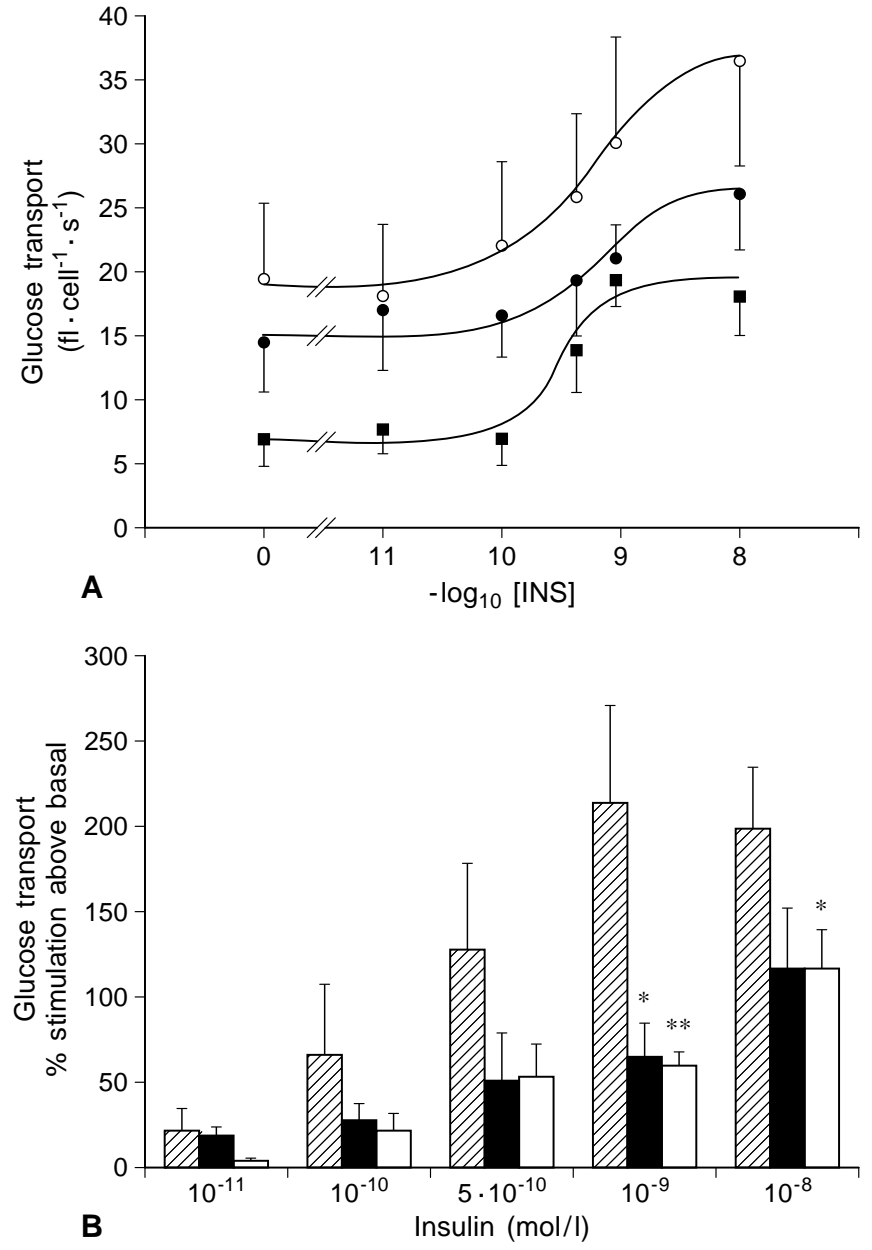

Fig. 1 (A , B ). Effect of insulin on glucose transport in adipocytes isolated from round ligament $\boldsymbol{\square}$, abdominal subcutaneous $\bigcirc$, and omental $\bigcirc$ tissues. (A) Fat cells were incubated with or without the indicated concentrations of insulin and glucose transport was determined as described in Methods. (B) Glucose transport stimulation at various concentrations of insulin corrected for basal transport rates. $\mathbb{Z}$, Round ligament; $\square$, subcutaneous; $\square$, omental Data are mean \pm SEM of 5-6 individual experiments. Fat cell weights were (in $\mu \mathrm{g}$ lipid/cell) for subcutaneous: $0.65 \pm 0.052$, round ligament: $0.90 \pm 0.056$, and omental cells: $0.58 \pm 0.056$. $* p<0.05, * * p<0.01$ vs round ligament cells

Furthermore, the mean waist-hip ratio of $0.84 \pm 0.06$ indicated that these patients tended to show a high proportion of abdominal adipose tissue. As expected, fasting insulin levels were elevated as compared to those observed in moderately obese premenopausal women of similar age [32]. However, fasting glycaemia and triglyceridaemia were quite normal or only slightly elevated. Total plasma cholesterol, as well as LDL- and HDL-cholesterol levels were within the normal range in these massively obese women (data not shown).

E ffects of insulin on glucose transport and lipolysis. The effects of insulin on glucose transport in 

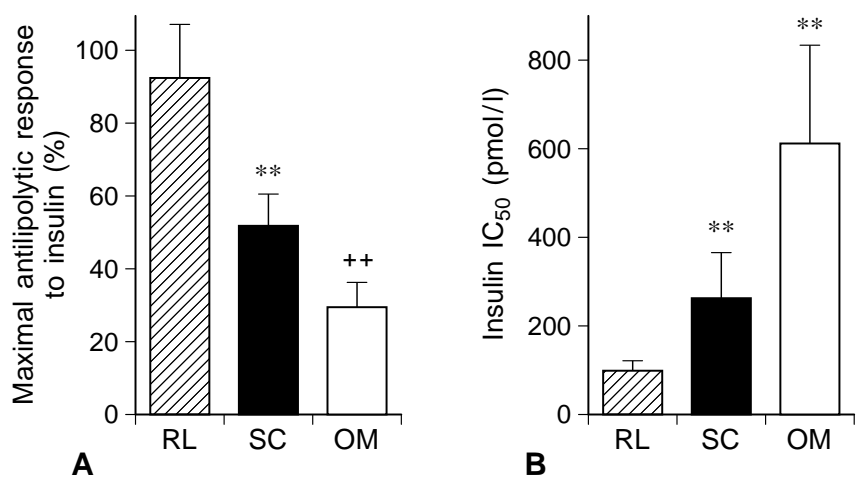

Fig. 2 (A, B ). Regional variation in the antilipolytic effect of insulin in isolated fat cells. Adipocytes from the round ligament (RL), abdominal subcutaneous (SC) and omental (OM) depots were incubated with $5 \mu \mathrm{g} / \mathrm{ml}$ adenosine deaminase (ADA) in the presence or absence of various concentrations of insulin. Maximal antilipolytic effects (A) as well as the sensitivity $\left(\mathrm{IC}_{50}\right)$ to insulin (B) are depicted. Basal and ADA-stimulated lipolysis (in nmol glycerol $\cdot 10^{8} \mu \mathrm{m}^{-2} 10^{8} \cdot 2^{-1} \mathrm{~h}$ ) values were, respectively: RL, $2.48 \pm 0.39$ and $5.42 \pm 1.02$; SC, $4.05 \pm 0.49$ and $10.44 \pm 1.56 ; \mathrm{OM} 2.50 \pm 0.28$ and $6.11 \pm 1.29$. Values are means \pm SEM of 6-7 individual experiments performed in duplicate. $* * p<0.01$ vs round ligament fat cells, $++p<0.01$ vs both round ligament and abdominal subcutaneous adipocytes

adipocytes isolated from the three adipose depots are shown in Figure 1. Basal and insulin-stimulated glucose transport rates varied quite significantly between subjects (Fig.1A). The difference in absolute rates of transport between the subjects or within each cell type was not related to variation in cell surface area (see legend to Fig. 1). Basal glucose transport tended to be greater in omental fat cells as compared to adipocytes from the other depots. Insulin stimulated glucose transport in a dose-dependent fashion in cells from all adipose regions, with maximal (2-3 times) increases at $10^{-9}-10^{-8} \mathrm{mmol} / \mathrm{l}$ (Figs. $1 \mathrm{~A}$ and $\mathrm{B})$. When insulin action was expressed as percent stimulation above basal in order to correct for interindividual variation in basal glucose transport rates, maximal insulin stimulation (observed at $10^{-9}$ $10^{-8} \mathrm{mmol} / \mathrm{l}$ ) was significantly higher in round ligament fat cells as compared to omental and subcutaneous adipocytes (Fig. 1B). The sensitivity of round ligament adipose cells to insulin also tended to be greater than that observed in the other fat cells, although the difference failed to reach statistical significance $(p=0.13)$. The half-maximal effective dose of insulin $\left(\mathrm{EC}_{50}\right)$ was $0.38 \pm 0.16 \mathrm{nmol} / \mathrm{l}$ for round ligament adipocytes as compared to $1.12 \pm 0.35 \mathrm{nmol} / \mathrm{l}$ and $0.91 \pm 0.25 \mathrm{nmol} / \mathrm{l}$ for subcutaneous and omental adipose cells, respectively.

In addition to glucose transport, regional variation was also found for the inhibitory action of insulin on adipocyte lipolysis. As shown in Figure 2, the ability of insulin to inhibit ADA-stimulated glycerol release was higher in round ligament adipocytes

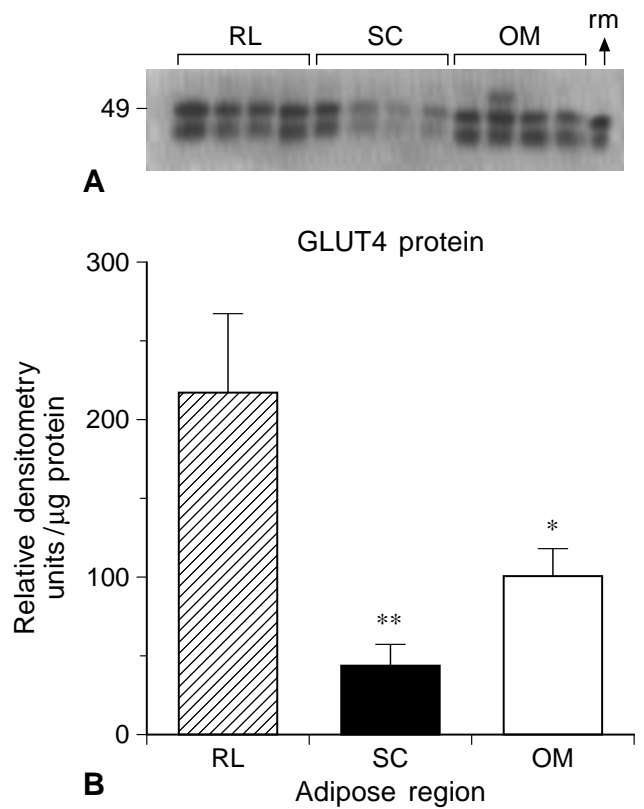

Fig. 3 (A, B). GLUT4 protein expression in round ligament (RL), abdominal subcutaneous (SC), and omental (OM) adipose tissues. Equivalent amounts of proteins $(5 \mu \mathrm{g})$ were subjected to SDS-PAGE on $7.5 \%$ polyacrylamide gels and transferred to PVDF membranes for immunoblotting with a polyclonal antibody against GLUT4. The immunoreactive bands were detected as described in Methods. (A) Representative immunoblot showing GLUT4 transporter abundance in adipose tissues from four different subjects. GLUT4 was detected as a double band (Results) migrating at approximately 46-48 $\mathrm{kDa}$ in both adipose tissues and rat skeletal muscle (rm). (B) Scanning data (means \pm SEM) showing GLUT4 relative densitometric units per $\mu \mathrm{g}$ protein in adipose tissues from nine subjects. $* p<0.05 ; * * p<0.01$ vs round ligament adipose tissue

$(p<0.005)$ as compared to the other adipose cells (Fig. 2A). However, in subcutaneous fat cells, insulin inhibition of lipolysis was still significantly higher than that observed in omental adipocytes $(p<0.005)$. Furthermore, insulin sensitivity for inhibition of lipolysis was greater in round ligament adipocytes than in either subcutaneous or omental fat cells $(p<0.01)$ (Fig. 2B).

GLUT 4 expression in adipose tissues. We further investigated whether regional differences in insulin action on glucose metabolism may be related to a differential expression of the GLUT4 glucose transporter in adipose cells from the three depots. Total adipose tissue membranes were isolated and equivalent amounts of proteins were resolved on SDS-PAGE. Immunoblotting was performed using a GLUT4-specific polyclonal antibody. A representative Western blot is shown in Figure 3A. The GLUT4 protein migrated as a double band of about 46 and $48 \mathrm{kDa}$ (see Methods) in membranes isolated from all fat depots as well as in a rat skeletal muscle membrane sample used as an internal control for gel comparisons. Relative GLUT4 protein levels were 5 times and 2.2 times 

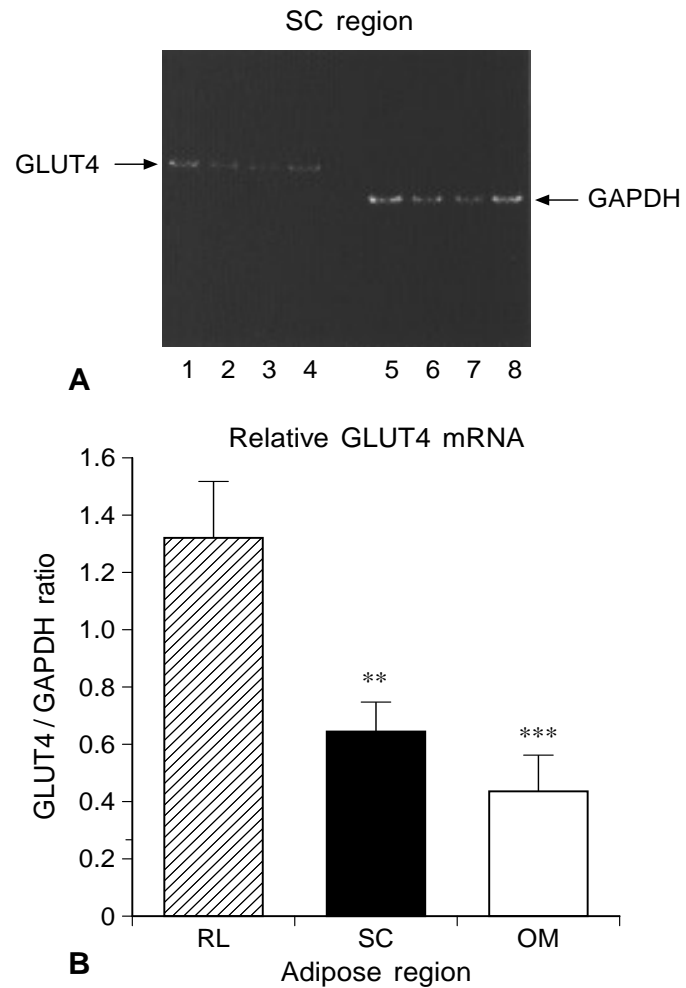

Fig. 4. GLUT4 mRNA expression in round ligament (RL), abdominal subcutaneous (SC), and omental (OM) adipose tissues. Cellular RNA was purified and GLUT4 mRNA was determined by semi-quantitative RT-PCR analysis as described in Methods. GAPDH mRNA was also measured in the same samples and was used as an internal control for the PCR assay. (A) Representative experiment showing GLUT4 (lanes 1-4) and GAPDH (lanes 5-8) amplifications in abdominal subcutaneous fat from four different subjects. (B) Relative GLUT4 mRNA levels expressed as GLUT4/GAPDH ratio in $\mathrm{RL}, \mathrm{SC}$ and OM adipose depots. Bars represent mean \pm SEM of $6-8$ subjects. **p $<0.01$ vs RL adipose tissue

greater in round ligament than in subcutaneous and omental adipose regions, respectively (Fig. 3B). No significant difference in GLUT4 abundance was found between the two latter depots. Similar results were obtained when the relative amounts of either the lower or the upper GLUT4 bands were analysed separately (data not shown).

When sufficient amounts of adipose tissue were removed $(n=6-8)$, we also assessed the expression of the GLUT4 gene in the different regions by measuring GLUT4 mRNA levels. GAPDH mRNA levels assessed in the same samples were used as internal controls for the RT-PCR assay. A representative experiment is shown in Figure 4A. GLUT4 and GAPDH were both amplified as single gene products migrating at the expected molecular size (GLUT4: $382 \mathrm{bp}$, GAPDH: $331 \mathrm{bp}$ ) on agarose gels. GLUT4/GAPDH ratios were calculated and the average values are presented in Figure 4B. Round ligament adipose tissue showed higher GLUT4 mRNA levels than subcutaneous and omental fat depots $(p<0.01)$. GLUT4 mRNA levels were not significantly different between the two latter adipose regions. It is interesting to note that a significant positive relationship $(r=0.63, p<0.005)$ was observed between GLUT4 protein and mRNA levels in the adipose tissue samples in which both parameters could be determined.

Relationship of GL UT4 expression with the subject's metabolic characteristics. Adipose GLUT4 mRNA levels were positively associated with both fasting insulinaemia and glycaemia, although some associations failed to reach statistical significance (Table 2). In contrast, no relationship was observed between GLUT4 protein amounts and fasting plasma insulin or glucose levels, with the exception of the round ligament adipose depot in which the transporter protein was associated with fasting insulinaemia. No significant relationship was found between GLUT4 mRNA or protein levels and triglyceride levels (Table 2). Furthermore, GLUT4 protein levels were correlated with neither fat mass, percent body fat nor with the body mass index (Table 2). However, these adiposity indices were positively associated with GLUT4 mRNA levels determined in round ligament adipose tissue but not in the other depots. Interestingly, amounts

Table 2. Correlation coefficients between adipose tissue GLUT4 protein and mRNA levels and subject's metabolic/morphometric characteristics

\begin{tabular}{|c|c|c|c|c|c|c|}
\hline \multirow[t]{2}{*}{ Parameters } & \multicolumn{3}{|l|}{ GLUT4 protein } & \multicolumn{3}{|c|}{ Glut4 mRNA } \\
\hline & Round ligament & $\begin{array}{l}\text { Abdominal } \\
\text { subcutaneous }\end{array}$ & Omentum & $\begin{array}{l}\text { Round } \\
\text { ligament }\end{array}$ & $\begin{array}{l}\text { Abdominal } \\
\text { subcutaneous }\end{array}$ & Omentum \\
\hline $\mathrm{n}$ & 9 & 9 & 9 & 6 & 8 & 6 \\
\hline Insulin (pmol/1) & $0.70^{\mathrm{a}}$ & 0.05 & 0.07 & 0.57 & $0.63^{\mathrm{a}}$ & 0.59 \\
\hline Glucose $(\mathrm{mmol} / \mathrm{l})$ & 0.35 & 0.13 & 0.30 & $0.90^{\mathrm{b}}$ & 0.49 & $0.79^{\mathrm{a}}$ \\
\hline Triglycerides $(\mathrm{mmol} / \mathrm{l})$ & -0.26 & -0.30 & 0.03 & 0.19 & -0.31 & -0.36 \\
\hline Body mass index $\left(\mathrm{kg} / \mathrm{m}^{2}\right)$ & 0.07 & 0.03 & 0.48 & $0.70^{\mathrm{a}}$ & -0.57 & -0.22 \\
\hline Waist circumference $(\mathrm{cm})$ & -0.48 & -0.64 & 0.03 & 0.27 & -0.24 & -0.21 \\
\hline Waist-to-hip ratio & $-0.79^{\mathrm{b}}$ & $-0.85^{\mathrm{b}}$ & $-0.89^{\mathrm{b}}$ & -0.65 & -0.53 & -0.11 \\
\hline
\end{tabular}

${ }^{\mathrm{a}} \mathrm{p}<0.05 ;{ }^{\mathrm{b}} \mathrm{p}<0.01$ 
of GLUT4 protein were strongly $(p<0.01)$ and negatively correlated with the waist-to-hip ratio in all depots investigated.

\section{Discussion}

The present results show that insulin stimulates glucose transport in human adipocytes isolated from three different anatomical locations. The stimulation of glucose transport by insulin in this study (2-3fold) is less important than that commonly reported in rat adipocytes (10-20-fold) [see [33] for review] but similar to that found in previous studies using human fat cells $[25,34,35]$. This apparent discrepancy is unlikely to be explained by methodological differences in adipocyte isolation since the magnitude of the antilipolytic effect of insulin was comparable to that observed in rat adipocytes. The species-related difference in insulin action on glucose transport has been recently reported to be related to a lower number of intracellular GLUT4 transporters to be recruited to the cell surface in human adipocytes, as a consequence of their larger size [36]. Indeed, the large human fat cells appear to have a greater proportion of cell surface GLUT4 in the basal state than the smaller rat adipocytes, presumably in order to meet greater metabolic needs. Although differences in fat cell size may explain inter-species variation in insulin responsiveness, they cannot account for the regional variations observed in the present study. Indeed, the more insulin responsive round ligament adipocytes were larger than subcutaneous and omental fat cells (Fig.1). Differences in GLUT4 expression, rather than fat cell size, appear to be responsible for the regional variations in insulin action on glucose transport (see below).

When considering absolute values, glucose transport was apparently lower in round ligament fat cells, both in the basal and insulin-stimulated states (Fig.1A). However, we found very important interindividual variations in the absolute rates of glucose transport in these subjects and we could not detect significant differences in absolute basal or insulinstimulated glucose transport rates between the fat cell types. In fact, insulin failed to significantly stimulate basal glucose transport in subcutaneous and omental fat cells when considering absolute values. However, when insulin action was expressed relative to the basal transport rate, these variations among subjects were greatly diminished and this allowed a better evaluation of insulin action among fat cell types (Fig. 1B). The per cent insulin stimulation was always higher for round ligament fat cells, and importantly, even in those patients where basal transport rates were comparable between fat cell types.

It is well known that glucose transport in adipose cells is mainly facilitated by the GLUT4 glucose transporters. Previous studies performed in normal and diabetic subjects have shown that insulin action on adipocyte glucose transport is associated with GLUT4 expression [37]. Our data further suggest that a differential expression of GLUT4 is responsible, at least in part, for the regional differences in adipocyte insulin action. Indeed, we found that round ligament adipocytes exhibited higher levels of GLUT4 as compared to the two other cell types. Similar to the GLUT4 protein abundance, GLUT4 mRNA levels were significantly greater in round ligament than in subcutaneous and omental adipose tissues, suggesting that variations in GLUT4 transcription could account for a large part of the site differences found in GLUT4 protein content. Differences in insulin-induced GLUT4 translocation may also contribute to the observed regional variations in insulin responsiveness. However, this hypothesis could not be verified in the present study because of the relatively small amount of tissue available.

In addition to its stimulatory effect on glucose transport, the ability of insulin to inhibit ADA-stimulated lipolysis was also assessed. Insulin-induced antilipolysis was also found to vary between fat cell types. Insulin blunted lipolysis to a greater degree in subcutaneous abdominal than in omental fat cells (Fig.2), confirming previous studies performed in moderately obese subjects [38]. Furthermore, as for glucose transport, round ligament fat cells showed the greatest sensitivity and responsiveness to the hormone. The fact that site differences in insulin action were not limited to glucose transport suggests the presence of regional variations at more proximal insulin signalling events in human adipocytes. Furthermore, round ligament adipose cells were not only more responsive but also more sensitive to insulin, suggesting that differences in insulin receptor number and/or affinity may also exist between these fat cell types. In this regard, variations in insulin receptor affinity [38], as well as in its autophosphorylation and tyrosine kinase activities [15] have been previously reported between adipocytes isolated from different regions. Further studies are required to determine whether differences in insulin receptor number and/or functional activities may also contribute to the greater insulin action on both glucose transport and lipolysis in round ligament adipose cells.

An unexpected finding in the present study was that regional variation in insulin-stimulated glucose transport was observed between adipocytes isolated from two intra-abdominal depots. Indeed, adipocytes from the round ligament were more insulin responsive than cells from the omental region. The physiological basis for the observed functional heterogeneity in insulin action among intra-abdominal adipose depots is still unclear. It has been proposed that an abnormally elevated release of NEFA by the enlarged deep abdominal adipose tissue may explain 
the association reported between visceral obesity and insulin resistance. Accordingly, studies conducted on both humans and animals have already shown that visceral fat cells are lipolytically more active than subcutaneous adipocytes [see $[2,7,13]$ for reviews]. The greater lipolysis of omental fat cells appears to be related to the weaker antilipolytic actions of both insulin and adrenaline ( $\alpha_{2}$-adrenoceptor-component), as well as to the higher lipolytic effect of catecholamines ( $\beta$-adrenoceptor pathway) when compared to other fat cell types [24, 38-43]. However, the present study indicates that in contrast to omental adipose cells, intra-abdominal round ligament adipocytes are unlikely to release high levels of NEFA in the portal circulation but are rather efficient in storing triglycerides. Based on the subjects' plasma insulin levels (Table 1 ), round ligament adipocyte lipolysis would be largely inhibited in vivo, even in the fasting state. Moreover, we have recently reported that lipoprotein lipase activity is higher but that the lipolytic sensitivity to adrenaline is reduced in round ligament cells as compared to omental cells [24], explaining the greater fat cell weight of the former cell type. Furthermore, most of the glucose taken up by adipose cells in the presence of insulin is used for re-esterification of fatty acids, hence reducing their net release in the circulation. Since round ligament fat cells show the greatest responsiveness to insulin, it appears plausible that a large part of the glucose extracted by these cells could be used for re-esterification of fatty acids. Furthermore, since properitoneal fat (i.e. the round ligament) is quantitatively much more important than the intraperitoneal fat of the omentum, the increased insulin responsiveness of round ligament adipose cells may be physiologically relevant from a quantitative point of view. In future studies, we will attempt to determine the relative contribution of properitoneal fat cells to total body fat mass (i.e. by computed tomography) in order to evaluate more precisely its physiological impact and whole-body glucose and lipid homeostasis.

Taken together, our results suggest that round ligament fat cells may serve to limit the impact of intraabdominal obesity on insulin resistance by reducing the release of NEFA in the portal vein. In this regard, it is interesting to note that the subjects' metabolic profile was not overtly deteriorated (Table 1), despite the severity of their obesity. On the other hand, it is also important to note that the regional variation in adipocyte insulin action described in the present study was observed in morbidly obese premenopausal women. Whether such differences also occur in normal lean individuals or are linked to the development of an obese state and its associated complications is still unknown.

Despite the existence of regional variation in adipose tissue GLUT4 expression, abdominal obesity (crudely assessed by the waist-hip ratio) was negatively correlated with GLUT4 protein content in all adipose regions investigated. However, no significant association was found between adipose GLUT4 protein abundance and the waist circumference, probably a better index of visceral obesity in these morbidly obese women [44]. We have recently proposed that the waist-hip ratio may represent an index of the relative accumulation of abdominal adipose tissue, independently from the degree of obesity [44]. Thus, GLUT4 protein levels may be associated with the distribution of adipose tissue in the abdominal region rather than with the absolute amount of visceral fat. More direct assessment of intra-abdominal adipose mass by computed tomography may help resolve this issue in further studies.

In summary, the present study shows the existence of regional variations in adipose tissue insulin action in morbidly obese women. The greater insulin action on glucose transport in round ligament adipocytes is associated with a higher expression of GLUT4 when compared to subcutaneous and omental fat cells. The greater expression of GLUT4 in round ligament adipose tissue appears to be mainly explained by a higher transcription of the GLUT4 gene although post-transcriptional mechanisms cannot be ruled out.

A cknowledgements. The authors wish to thank Ms. M. Marcotte, Ms. F. Levasseur, Ms. J. Maheux, Ms. J. Hovington, Mr. H. Bessette and Mr. C. Leblanc of the Physical Activity Sciences Laboratory for their excellent collaboration at various stages of the study. The subjects and the Physical Activity Sciences Laboratory staff are also gratefully acknowledged. We would also like to thank Ms. M. Martin and Ms. R. Duchesne of the Diabetes Research Unit for their valuable technical assistance. Thanks are also expressed to the surgical staff of the Laval Hospital, for providing us with adipose tissue specimens.

\section{References}

1. Després, J-P (1993) Abdominal obesity as important component of insulin-resistance syndrome. Nutrition 9(5): 452-459

2. Björntorp, P (1993) Visceral obesity: a "civilization syndrome" Obesity Res 1: 206-222

3. Park KS, Rhee B, Lee K-U, Kim S, Lee H, Koh C, Min H (1991) Intra-abdominal fat is associated with decreased insulin sensitivity in healthy young men. Metabolism 40: 600-603

4. Banerji MA, Chaiken RL, Gordon D, Kral JG, Lebovitz HE(1995) Does intra-abdominal adipose tissue in black men determine whether NIDDM is insulin-resistant or insulin-sensitive? Diabetes 44(2):141-146

5. Carey DG, Jenkins AB, Campbell LV, Freund J, Chisholm DJ (1996) Abdominal fat and insulin resistance in normal and overweight women. Direct measurements reveal a strong relationship in subjects at both low and high risk of NIDDM. Diabetes 45: 633-638

6. Roust LR, Jensen MD (1993) Post prandial free fatty acid kinetics are abnormal in upper body obesity. Diabetes 42 : 1567-1573 
7. Kissebah AH, Krakower GR (1994) Regional adiposity and morbidity. Physiol Rev 74: 761-811

8. Foley JE (1992) Rationale and application of fatty acids oxidation inhibitors in treatment of diabetes mellitus. Diabetes Care 15: 773-784

9. Arner P(1990) Metabolism of fatty acids: an overview. In: GA Bray, D Ricquier, BM Spiegelman (eds) Obesity: towards a molecular approach. Alan Liss, New York pp 159172

10. Marin P, Rébuffé-Scrive M, Smith U, Björntorp P (1987) Glucose uptake in human adipose tissue. Metabolism 36: 1154-1160

11. Crandall DL, Fried SK, Francedese AA, Nickel M, Digirolamo M (1983) Lactate released in isolated rat adipocytes: influence of cell size, glucose concentration, insulin and epinephrine. Horm Metab Res 15: 326-329

12. Arner P (1988) Control of lipolysis and its relevance to development of obesity in man. Diabetes Metab Rev 4: 507515

13. Bouchard C, Després JP, Mauriège P (1993) Genetic and nongenetic determinants of regional fat distribution. Endocr Rev 14(1):72-93

14. Fried SK, Lavau M, Pi-Sunyer FX (1982) Variations in glucose metabolism by fat cells from three different depots of the rat. Metabolism 31: 876-883

15. Sztalryd C, Azhar S, Reaven GM (1991) Differences in insulin action as a function of original anatomic site of newly differentiated adipocytes obtained in primary culture. J Clin Invest 88: 1629-1635

16. Gray H (1973) The liver. In: CM Goss (ed) Anatomy of human body. Lea and Febiger Philadelphia, pp. 1244-1253

17. Behnke AR, Wilmore JH (1974) Evaluation and regulation of body build and composition. Prentice-Hall, Englewood Cliffs, NJ

18. Siri WE (1956) The gross composition of body fat. Adv Biol Med Phys 4: 239-280

19. Meneely GR, Kaltreider NL (1949) Volume of the lung determined by helium dilution. J Clin Invest 28: 129-139

20. Lohman TG, Roche AF, Martorell R (1988) The Airlie (VA) consensus conference. Anthropometric standardisation reference manual. Human Kinetics Publishers Inc., Champaign, Illinois, 39-80

21. Mauriège $\mathrm{P}$, Marette A, Atgie C (1995) Regional variation in adipose tissue metabolism of severely obese premenopausal women. J Lipid Res 36: 672-684

22. Rodbell M (1964) Metabolism of isolated fat cells. I-Effects of hormones on glucose metabolism and lipolysis. J Biol Chem 239: 375-380

23. Després J-P, Bouchard C, Bukowiecki L, Savard R, Lupien J (1983) Morphology and metabolism of human fat cells: a reliability study. Int J Obes 7: 231-240

24. Mauriège P, Marette A, Atgié C (1995) Regional variation in adipose tissue metabolism of severely obese premenopausal women. J Lipid Res 36: 672-684

25. Kashiwagi A, Verso MA, Andrews J, Vasquez B, Reaven G, Foley JE (1983) In vitro insulin resistance of human adipocytes isolated from subjects with noninsulin-dependent diabetes mellitus. J Clin Invest 72: 1246-1254

26. Marette A, Bukowiecki LJ (1989) Stimulation of glucose transport by insulin and norepinephrine in isolated rat brown adipocytes. Am J Physiol 257(Cell Physiol 26):C714-C721

27. Laemmli UK (1970) Cleavage of structural proteins during the assembly of the head of bacteriophage T4. Nature (London) 227: 680-685
28. Marette A, Atgie C, Liu Z, Bukowiecki LJ, Klip A (1993) Differential regulation of GLUT1 and GLUT4 glucose transporters in skeletal muscle of a new model of type-II diabetes - the obese SHR/N-cp rat. Diabetes 42(8):11951201

29. Kikkawa F, Nawa A, Oguchi H (1994) Positive correlation between cytochrome p450 2E1 mRNA level and serum estradiol level in human uterine endometrium. Oncology 51(1):52-58

30. Liu S, Adcock IM, Old RW, Barnes PJ, Evans TW (1993) Lipopolysaccharide treatment in vivo induces widespread tissue expression of inducible nitric oxide synthase mRNA. Biochem Biophys Res Comm 196(3):1208-1213

31. Chomczynski P, Sacchi N (1984) Single-step method of RNA isolation by acidic guanidium thiocyanate-phenolchloroform extraction. Anal Biochem 162: 156-159

32. Després J-P, Moorjani S, Lupien PJ, Tremblay A, Nadeau A, Bouchard C (1990) Regional distribution of body fat, plasma lipoproteins and cardiovascular disease. Arteriosclerosis 10: 497-511

33. Simpson IA, Cushman SW, Egan JJ et al. (1990) Hormonal regulation of glucose transport in rat adipose cells. Biochem Soc Trans 18(6):1123-1125

34. Ciaraldi TP, Kolterman OG, Siegel JA, Olefsky JM (1979) Insulin-stimulated glucose transport in human adipocytes. Am J Physiol 236:E621-E625

35. Zeuzem S, Jungmann E, Henne T, Schöffling K (1989) Assessment of D-glucose uptake in isolated human adipocytes. Comparison of two validated and standardized methods. Horm Metab Res 21(3):156-157

36. Kozka IJ, Clark AE, Reckless JP, Cushman SW, Gould GW, Holman GD (1995) The effects of insulin on the level and activity of the GLUT4 present in human adipose cells. Diabetologia 38: 661-666

37. Kahn BB (1992) Alterations in glucose transporter expression and function in diabetes: mechanisms for insulin resistance. J Cell Biochem 48(2):122-128

38. Bolinder J, Kager L, Ostman J, Arner P (1983) Differences at the receptor and post-receptor levels between human omental and subcutaneous adipose tissue in the action of insulin on lipolysis. Diabetes 32: 117-123

39. Hellmer J, Marcus C, Sonnenfeld T, Arner P (1992) Mechanisms for differences in lipolysis between human subcutaneous and omental fat cells. J Clin Endocrinol Metab 75(1):15-20

40. Fried SK, Leibel RL, Edens NK, Kral JG (1993) Lipolysis in intra-abdominal adipose tissues of obese women and men. Obes Res 1: 443-448

41. Mauriège P, Galitzky J, Berlan M, Lafontan M (1987) Heterogeneous distribution of beta and alpha-2 adrenoceptor binding sites in human fat cells from various fat deposits: functional consequences. Eur J Clin Invest 17(2):156-165

42. Rebuffé-Scrive M, Andersson B, Olbe L, Björntorp P (1989) Metabolsim of adipose tissue in intra-abdominal depots on nonobese men and women. Metabolism 38: 453458

43. Rebuffé-Scrive M, Andersson B, Olbe L, Björntorp P (1990) Metabolism of adipose tissue in intra-abdominal depots of severely obese men and women. Metabolism 39: 1021-1025

44. Pouliot MC, Després JP, Lemieux S et al. (1994) Waist circumference and abdominal sagittal diameter: best simple anthropometric indexes of abdominal visceral adipose tissue accumulation and related cardiovascular risk in men and women. Am J Cardiol 73: 460-468 